Элиша Саливон

(Штутгарт, Германия)

Университет Штутгарта

аспирант

E-mail: oleksiysalivon@yahoo.de

ORCID 0000-0002-1995-1856

\title{
Paul. R Magocsi and Y. Petrovsky-Shtern. Jews and Ukrainians. A Millennium of Co-Existence.
}

\author{
Toronto: University of Toronto Press, Scholarly Publishing \\ Division, 2016. ISBN-13: 978-0772751119. 320 p.
}

DOI: $10.31168 / 2658-3364.2020 .2 .19$

В своей новой совместной иллюстрированной книге П. Магочий и Й. Петровский-Штерн обратились к тематике истории еврейского и украинского населения современной Украины. В своей работе они исходили из предположения, что средний обыватель не знаком ни с историей еврейского народа, проживающего на территории современной Украины, ни с историей взаимоотношений евреев и украинцев друг с другом на протяжении практически целого тысячелетия [Магочий и Петровский-Штерн 2016, 1].

Оставив в стороне взаимные еврейские и украинские предубеждения, известные нам сегодня из непростой истории взаимоотношений обеих этнических групп в разные исторические эпохи, авторы поставили своей целью, создать параллельный общий нарратив еврейской и украинской истории [Там же]. Авторы выделили несколько определенных аспектов, в которых они проследили последовательность исторических событий, к примеру, историю создания еврейских и украинских населенных пунктов, религию, театр, архитектуру и др. Как они сами сформулировали свою цель, они попытались представить свое видение украинско-еврейского сосуществования в различных областях жизни, чтобы выявить как различия, так и параллели [Там же].

По их словам, один из соавторов работал в основном с материалами по истории этнических украинцев, в то время как второй уделял основное внимание еврейской тематике, хотя иногда, они писали и по основным темам друг друга [Там же]. Таким образом, как мы увидим в дальнейшем описании, данная книга несомненно является не просто 
публикацией двух работ, связанных лишь общими географическими рамками, но органическим произведением, в котором история обоих народов отражает сложную взаимозависимую политическую, культурную и социальную динамику Восточной Европы.

Если же первоначальной целью авторов было желание познакомить будущих читателей своей книги с самобытной культурной жизнью и непохожестью исторических судеб этих двух народов, то к концу работы два отдельных исторических нарратива слились в единый рассказ, в котором схожесть и различия исторических судеб, представили читателям единую, цельную и неразрывную историческую картину.

Действительно, позиция авторов, заключающаяся в том, что эти два гетерогенных народа в силу разных причин делят определенный исторический нарратив, заслуживает внимания [Там же]. Контакт этих этнических групп произошел в сложной и многообразной языковой, культурной, политической среде, которая формировала облик Восточной Европы на протяжении тысячи лет, и, несомненно, взаимовлияние евреев и этнических украинцев должно прослеживаться не только в стереотипных и зачастую негативных представлениях друг о друге, но и во всех сферах общественной жизни как различных этнических групп, так и в частной жизни отдельного индивидуума [Там же].

Одной из удачных особенностей книги является тот факт, что авторы не ограничиваются какими-то конкретными областями жизни общества, и предлагают читателю комплексную картину развития отношений между двумя этническими группами, евреями и украинцами. В то же время в начале книги они уделяют значительное внимание одному из самых болезненных вопросов отношений между любыми этническими группами, а именно взаимным стереотипам и предубеждениям. Оба автора выразили убежденность, что только знание истории способно изжить подобного рода негативные пережитки прошлого, и способствовать пониманию и взаимоуважению [Магочий и Петровский-Штерн 2016, 2].

Во введении читатель встретится с перечислением подобного рода стереотипов и образов чужака, которые отражают непростую историю отношений между двумя народами, истоки которых, по мнению авторов, прослеживаются начиная с первых десятилетий XVI в., когда, собственно, и начинается эпоха по-настоящему значительных, как количественно, так и качественно, связей между евреями и украинцами на территории современной Украины [Там же].

Рецензируемая книга состоит из двенадцати глав, каждая из которых является вполне самостоятельным научным исследованием на определённую тему от архитектуры и искусства до языковой ситуации. Книга постоянно открывает новые грани сложного процесса взаимоотношений украинцев и евреев в совершенно различных плоскостях 
жизни, приводится множество примеров как отдельных исторических и общественных деятелей, так и простых обывателей из разных эпох, которые позволяют лучше понять исследуемые явления и их влияние на жизнь и идентичность евреев и украинцев.

Евреи, даже будучи этническим меньшинством, смогли сохранить свою культурную, языковую и религиозную самобытность, которая находилась в постоянном контакте с украинской культурой, заимствовала из нее, и в то же время сама оказывала определенное влияние на украинские культурные процессы. Авторы предоставили убедительную доказательную базу того, что еврейскую и украинскую историю можно рассматривать как взаимодополняющие дисциплины, и что без знания одной из них трудно понимать всю историю Украины как единое целое [Там же]. Книга отличается большим количеством прекрасных иллюстраций и различных карт, что позволяет читателю также задействовать и визуальное восприятие информации. Данный подход облегчает работу с материалом и дополняет его.

Первая глава «Страна и ее народы», которая является самой небольшой по объему дает представление о географии региона, в котором состоялась встреча еврейского и украинского народа. Также дается краткий обзор изменений в этническом составе населения территории современной Украины в последние несколько столетий, упоминаются другие основные этнические группы, чья численность не была постоянной, как-то поляки, русские, немцы и др. Данная глава должна послужить хорошим подспорьем для широкого круга читателей, которые начинают свое знакомство с историей разных этнических групп Восточной Европы. Вторая глава «Историческое прошлое» является одной из важнейших в данной работе. Как и предполагает ее название, глава охватывает историческое прошлое от причерноморских и степных цивилизаций до распада Советского союза в 1991 г. Стоит отметить несколько наиболее важных вех украинской истории, затронутых авторами, поскольку именно они привели к формированию еврейского, зачастую стереотипного, образа в украинском народном сознании, и наоборот, образа украинца - в еврейском.

В начале главы читатель знакомится с возникновением крымчакской и караимских общин, или как определяли их в последующем турецкие власти в северном Причерноморье «евреи с пейсами» и «евреи без пейсов» [Магочий и Петровский-Штерн 2016, 15]. Не остается без внимания и средневековая легенда о принятии хазарским царем Буланом иудаизма в VIII в., которая по мнению авторов имеет параллели как в украинской, так и в российской истории, в виде повествования о «выборе веры» языческим правителем. Следующим историческим этапом является становление средневекового восточнославянского государства с центром в Киеве, которое становится наиболее значи- 
тельным государством в данном регионе, принимает православную форму христианства и входит в контакт со степными народами к востоку, Византией к югу, и феодальной Европой к западу от своих границ.

Военные столкновения восточнославянских княжеств с кочевниками привели к окончательному распаду Киевской Руси под ударами монголов в XIII в., разрушению основных городских центров на территории современной Украины и временному переносу политического центра во Львов, который стал столицей независимого Галицко-Волынского княжества, а затем и одноименного королевства. Королевство просуществовало до середины XIV в. Таким образом обширные территории, которые сегодня находятся в пределах современной Украины, становятся частями Золотой Орды, одного из ее наследников Крымского ханства, Великого княжества Литовского, Королевства Польского, Королевства Венгрии и Молдавского княжества.

В качестве одного из интереснейших свидетельств существования еврейской общины в Киеве приводится информация касательно «Киевского письма», найденного в знаменитой Каирской генизе, которое относиться к середине X в. Под этим историческим источником подразумевается документ, выданный общинными лидерами киевской еврейской общины одному из евреев, который в результате ограбления потерял взятые в долг деньги и находился в поиске финансовой помощи для выплаты данного долга.

Как полагают авторы, именно во времена существования Киевской Руси на ее земли прибывают говорящие на идише евреи-ашкеназы вероятно из Богемии и Моравии. Хотя точное время их прибытия неизвестно, предполагается, что в XIII в. небольшие организованные общины ашкеназов уже существовали в центральных и северных городах современной Украины, таких как Острог, Владимир и Чернигов [Магочий и Петровский-Штерн 2016, 18].

Какова бы ни была история становления первых еврейских ашкеназских общин на Руси, авторы приходят к выводу, что к XV в. идиш становится основным разговорным языком общения внутри еврейского населения, а его носители, говорящие на идише ашкеназы определяют религиозное, общинное и культурное развитие еврейских общин данного региона [Магочий и Петровский-Штерн 2016, 19].

Авторы кратко описали появление новых государственных образований, таких как Королевство Польское, Великое княжество Литовское и Крымское ханство, а также феномен украинского казачества. Социально-экономическое развитие украинских земель, которые оказались под властью польской короны сопровождалось стратификацией местного населения, большая часть которого стала зависимым крестьянством, привязанным к землям польских магнатов. К концу XVI в. небольшую часть землевладельцев составляли православная 
шляхта, горожане, казаки на польской службе и свободные казаки, поселившиеся за днепровскими порогами.

Данное социальное деление усугублялось религиозным, существовали две церкви восточного ритуала, терпимая властями православная и официально признаваемая униатская [Магочий и Петровский-Штерн $2016,19]$. Данное экономическое, религиозное и социальное расслоение окажет значительное влияние на украинскую историю последующих веков, и будет прослежено в данном историческом труде вплоть до современного периода.

Стоит отметить, что каждый исторический период, представлен в книге последовательно, переход от одного к другому происходит плавно и сопровождается не только изложением исторических событий, но дает цельную картину происходящего, в контексте более широкой истории региона, на который также оказывают влияние соседи, такие как Крымское ханство, Польша и, впоследствии, Австро-Венгрия и Московское государство (позже - Российская империя). Затрагиваются темы антисемитизма, анти-иудаизма, социально-культурной жизни еврейского населения, его отношения с казачеством, вхождение украинских земель в соседние империи, черта оседлости, Первая и Вторая мировые войны, Холокост и многое другое. Представленный библиографический материал позволяет читателю, который хотел бы углубить свои знания в каком-либо конкретном вопросе, впоследствии самостоятельно обратиться к работам по данной теме или непосредственно к источникам.

Оставшиеся десять глав можно сгруппировать следующим образом: «Экономическая жизнь», «Традиционная культура», «Религия», «Язык и печать», «Литература и театр», «Архитектура и искусство», «Музыка» с одной стороны, «Диаспора», «Современная Украина» и «Прошлое, настоящее и будущее» - с другой. Главы, относящиеся к первой категории, дают тщательно проработанный обзор по каждой из обозначенных тем. Следует упомянуть несколько примеров, чтобы получить общее представление о том насколько авторам удалось их намерение представить несколько столетий еврейской и украинской истории в столь сжатом виде.

В главе «Экономическая жизнь», удачно описывается такое важное явление украинской культуры как корчма, которая в свою очередь была важнейшим элементом экономической жизни многих еврейских семей [Магочий и Петровский-Штерн 2016, 88]. Авторы простым и доступным языком не только описывают корчму как обычную торговую точку, но интерпретируют ее как социальный институт, как некого рода клуб, в котором помимо возможности поесть и выпить, протекали важные социальные процессы начиная от сватовства и заканчивая поиском работы [Там же]. 
Поскольку современная территория Украины входила в состав нескольких государств (к примеру, в XIX в. это были, Австро-Венгрия Габсбургов и Российская империя), то читатель знакомится также с параллельными процессами, протекавшими в этих государствах, таких как индустриализация, и их влиянием на различные этнические группы обеих империй [Магочий и Петровский-Штерн 2016, 94]. Следует упомянуть богато иллюстрированную главу «Архитектура и искусство, в которой прослеживается история Украины на примере, как ее архитектурных шедевров, так и самых распространенных архитектурных форм. В этой главе описывается органическая связь архитектуры еврейских культовых и общественных зданий в украинских городах и малых населенных пунктов с архитектурными формами восточноевропейского региона. Не остается без внимания и изобразительное еврейское и христианское искусство, как религиозное, так и светское [Магочий и Петровский-Штерн 2016, 200]. В части, посвященной музыкальной жизни украинцев и евреев, дается экскурс в историю клезмерской музыки, которую невозможно представить без музыкальных инструментов, таких как, например, цимбалы, общих для украинских и еврейских исполнителей [Магочий и Петровский-Штерн 2016, 221]. Авторам удалось описать роль различных компонентов культурной жизни, и то как обе этнические группы развивали свои самобытные элементы, к примеру, в танцах, таких как украинские - казачок, гопак, еврейские - хосидл, фрейлех, шер [Там же].

В одной из заключительных глав «Диаспора» авторы описывают феномен диаспоры не как некую абстрактную гомогенную украинскую общность, но как некий ряд различных украинских диаспор или диаспор из Украины [Магочий и Петровский-Штерн 2016, 231]. Данный подход авторы обуславливают гетерогенным составом территорий современной Украины как в прошлом, так и настоящем. В заключительной главе «Прошлое, настоящее и будущее», авторы высказывают надежду, что «два одиночества» со своими собственными нарративами, украинское и еврейское, сумеют однажды преодолеть отчуждение и создать единую историю существования еврейского и украинского народов на территории современной Украины [Магочий и Петровский-Штерн 2016, 285].

Несмотря на свой ограниченный объем, книга содержит несколько важных компонентов, которые делают ее хорошим образцом качественно проделанной работы. Упомянутые выше главы, дают наглядное представление о той обширной работе продельной авторами, о том насколько тщательно описаны основные события на макроуровне, выбраны интересные примеры на микроуровне и подобран библиографический материал. 
«Евреи и Украинцы. Тысяча лет жизни вместе» является новым важным исследованием, которое предлагает взглянуть на проблему межэтнических отношений в Восточной Европе, культурному взаимообмену между евреями и окружающим их населением, и формированию современной украинской и еврейской идентичности, как результата сложного исторического процесса.

\author{
Elisha Salivon \\ (Stuttgart, Germany) \\ PhD student, University of Stuttgart \\ E-mail: oleksiysalivon@yahoo.de \\ ORCID: 0000-0002-1995-1856
}

